\title{
Effects of rumen-degradable-to-undegradable protein ratio in ruminant diet on in vitro digestibility, rumen fermentation, and microbial protein synthesis
}

\author{
Ezi Masdia PutriD, Mardiati Zain (D), Lili Warly (D) and Hermon Hermon (D) \\ Department of Animal Nutrition, Faculty of Animal Science Andalas University, Kampus Limau Manis, Padang, \\ West Sumatera, Indonesia. \\ Corresponding author: Mardiati Zain, e-mail: mardiati@ansci.unand.ac.id \\ Co-authors: EMP: ezimasdia@gmail.com, LW: liliwarly_uapdg@yahoo.co.id, HH: herumonsan@yahoo.com \\ Received: 17-10-2020, Accepted: 02-02-2021, Published online: 17-03-2021
}

doi: www.doi.org/10.14202/vetworld.2021.640-648 How to cite this article: Putri EM, Zain M, Warly L, Hermon H (2021) Effects of rumen degradable-to-undegradable protein ratio in ruminant diet on in vitro digestibility, rumen fermentation, and microbial protein synthesis, Veterinary World, 14(3): 640-648.

\begin{abstract}
Background and Aim: Feeding ruminants must notice the degradability of feed, especially protein. Microbial rumen requires ammonia from rumen degradable protein (RDP) beside that ruminant require bypass protein or rumen undegradable protein (RUP) and microbial crude protein. The aim of the study was to discover the best RDP:RUP ratio in beef cattle diets commonly used by Indonesian farmers using an in vitro methodology.
\end{abstract}

Materials and Methods: Samples of Pennisetum purpureum, Leucaena leucocephala, Indigofera zollingeriana, cassava, maize, palm kernel cake, rice bran, and tofu waste were formulated into dietary treatments (dry matter [DM] basis). All experiments were carried out using a $3 \times 3 \times 2$ factorial, randomized block design with three replications. Treatments consisted of three protein levels $(12 \%, 14 \%$, and 16\%), two energy levels (65\% and 70\%), and three RDP:RUP ratio levels (55:45, 60:40, and 65:35). The experimental diets were incubated in vitro using buffered rumen fluid for $48 \mathrm{~h}$ at $39^{\circ} \mathrm{C}$. After incubation, the supernatants were analyzed to determine $\mathrm{pH}$, ammonia concentration, total volatile fatty acid (VFA), and microbial protein synthesis. The residues were analyzed to determine DM, organic matter, protein, and RUP digestibility.

Results: Increased protein, energy, and RDP levels increased digestibility, ammonia concentrations, total VFAs, and microbial protein synthesis $(\mathrm{p}<0.05)$, while rations with $16 \%$ protein lowered these parameters $(\mathrm{p}<0.05)$.

Conclusion: Increased dietary protein (from 12\% to 14\% DM), energy (from $65 \%$ to $70 \%$ DM), and RDP (from 55\% to $65 \%$ crude protein [CP]) levels increased nutrient digestibility, ammonia concentration, total VFA levels, and microbial protein synthesis. The diet containing 14\% DM dietary protein and 70\% DM energy, which contained 55\%, 60\%, or 65\% CP RDP optimally increased nutrient digestibility, ammonia concentration, total VFA levels, and microbial protein synthesis. Thus, feed based on these RDP:RUP ratios can optimize ruminant productivity.

Keywords: digestibility, microbial protein synthesis, protein, rumen characteristic, rumen degradable protein, rumen undegradable protein.

\section{Introduction}

Ruminant feeds must be based on the degradability of feed ingredients, especially protein since it is used by both the host animals and rumen microorganisms. Microbes require ammonia $\left(\mathrm{NH}_{3}\right)$ from protein degradation to form protein components of the cell wall. Ruminants require a true protein (bypass protein) and a microbial crude protein (CP) [1]. Thus, feeding a $\mathrm{CP}$-based diet could be ineffective in terms of ruminant productivity.

In ruminants, proteins can be divided into two types: Rumen degradable protein (RDP) and rumen undegradable protein (RUP). RDP is degraded by enzymes secreted by ruminal bacteria, such as protease,

Copyright: Putri, et al. Open Access. This article is distributed under the terms of the Creative Commons Attribution 4.0 International License (http://creativecommons.org/licenses/by/4.0/), which permits unrestricted use, distribution, and reproduction in any medium, provided you give appropriate credit to the original author(s) and the source, provide a link to the Creative Commons license, and indicate if changes were made. The Creative Commons Public Domain Dedication waiver (http://creativecommons.org/ publicdomain/zero/1.0/) applies to the data made available in this article, unless otherwise stated. peptidase, and deaminase, and is turned into peptides, amino acids, and $\mathrm{NH}_{3} \cdot \mathrm{NH}_{3}$ is then converted into microbial CP (MCP), which flows in the liquid and solid phases of digesta to be absorbed as amino acids and peptides in the intestine, thus providing 50\%-80\% of the absorbable true protein [2,3]. RUP is another true protein that is not degraded by rumen microbes, instead flows directly to the abomasum and small intestine for direct use by the host. RUP is digested in the small intestine, where approximately $80 \%$ is absorbed as amino acids with MCP for tissue utilization. RUP is important for providing high-quality amino acids to highly productive ruminants compared to MCP [4].

Ruminant protein has three major functions: (i) To meet the RDP requirements of rumen microbes for maximum carbohydrate digestion and maximal microbial protein synthesis; (ii) to provide the protein needed for host animal maintenance, growth, optimal health, and reproduction with minimal RUP intake; and (iii) to fulfill the amino acid requirements of highly productive ruminants using minimal dietary $\mathrm{CP}[1]$. Highly productive ruminants require a higher 
percentage of RUP in their diets to meet the amino acid requirements of the post-ruminal stage [5].

Efficient ruminant productivity requires optimal protein, energy levels, and RDP:RUP ratios in feed. Animal productivity can be increased by synchronizing the ruminal availability of carbohydrates and proteins [6]; whereas, non-synchronized protein and energy levels in feeds can reduce microbe protein synthesis. Furthermore, a low RDP level can decrease ruminal $\mathrm{NH}_{3}-\mathrm{N}$ levels, dry matter (DM) intake, and MCP. Excessive RDP will most likely be degraded to $\mathrm{NH}_{3}-\mathrm{N}$, which is absorbed into the blood, then converted to urea in the liver before being excreted in the urine [7].

In previous studies, increased RDP levels in ruminant diets significantly increased nutrient digestibility, rumen fermentation, and microbial protein synthesis [8,9]; however, there has been a lack of research on these protein fractions in the diet of ruminants in Indonesia. Thus, we aimed to determine the optimum RDP:RUP ratio in ruminant diets, using a ruminant feed commonly used for cattle in Indonesia, and determined the resulting nutrient digestibility, rumen fermentation, and microbial protein synthesis.

\section{Materials and Methods}

Ethical approval

This research did not use any live animals so, ethical approval is not needed.

\section{Study period and location}

This study was conducted from November 2019 to March 2020 at Ruminant Laboratory of Animal Science Faculty of Andalas University.

\section{Sample preparation and experimental diets}

The plant species samples (Pennisetum purpureum, Gliricidia sepium, and Indigofera zollingeriana) were collected and identified by the authors from the UPT Teaching Farm, Faculty of Animal Science, Andalas University, Padang, Indonesia. The samples were dried at $60^{\circ} \mathrm{C}$ for $24 \mathrm{~h}$ in a forced-air oven, and then milled through a $1 \mathrm{~mm}$ sieve. Cassava (Manihot esculenta), maize (Zea mays), palm kernel cake (palm oil or Elaeis guineensis), rice bran (paddy or Oryza sativa), and tofu waste were obtained from a poultry shop. The chemical analysis included proximate analysis, Van Soest analysis, and the determination of the RDP and RUP levels in each sample [10]. The samples were then formulated into rations based on protein, energy levels, and RDP:RUP ratio. The experiment used a $3 \times 3 \times 2$ factorial, randomized block design with three replications. Treatments consisted of three levels of protein $(12 \%, 14 \%$, and $16 \%)$, two levels of energy ( $65 \%$ and $70 \%$ ), and three levels of RDP:RUP ratio $(55: 45,60: 40$, and 65:35). The chemical composition of each treatment diet is given in Tables-1-3. The flow diagram of sample preparation and formulation is given in Figure-1.

\section{In vitro experiment}

The flow diagram of the experimental methodology is given in Figure 2. An in vitro experiment was performed using the Tilley and Terry method [11], to determine feed digestibility, rumen fermentation characteristics, and microbial protein synthesis. In this experiment, rumen liquor was obtained from

Table-1: Chemical composition diet for protein $12 \%$ DM.

\begin{tabular}{|c|c|c|c|c|c|c|}
\hline \multirow[t]{2}{*}{ Component } & \multicolumn{3}{|c|}{ 65\% TDN (DM) } & \multicolumn{3}{|c|}{ 70\% TDN (DM) } \\
\hline & RDP55 & RDP60 & RDP65 & RDP55 & RDP60 & RDP65 \\
\hline \multicolumn{7}{|l|}{ Ingredient composition (\%) } \\
\hline Elephant grass (Pennisetum purpureum) & 30 & 30 & 30 & 30 & 30 & 30 \\
\hline Leucaena leucocephala & 6 & 8 & 3 & 6 & 12 & 3 \\
\hline Indigofera zollingeriana & 2 & 4 & 8 & 2 & 2 & 9 \\
\hline Cassava (Manihot esculenta) & 12 & 15 & 24 & 12 & 31 & 21 \\
\hline Palm kernel cake (Elaeis guineensis) & 30 & 11 & 5 & 23 & 9 & 2 \\
\hline Maize (Zea mays) & 8 & 4 & 2 & 20 & 8 & 18 \\
\hline Rice bran (Oryza sativa) & 9 & 23 & 11 & 2 & 2 & 10 \\
\hline Tofu waste & 2 & 4 & 15 & 4 & 5 & 6 \\
\hline \multirow[t]{2}{*}{ Mineral } & 1 & 1 & 1 & 1 & 1 & 1 \\
\hline & 100 & 100 & 100 & 100 & 100 & 100 \\
\hline \multicolumn{7}{|l|}{ Chemical composition (\% DM) } \\
\hline DM & 89.37 & 89.36 & 88.91 & 88.62 & 89.32 & 88.37 \\
\hline RDP (\%CP) & 56.00 & 62.40 & 64.56 & 56.82 & 60.13 & 64.26 \\
\hline RUP (\%CP) & 43.00 & 36.60 & 33.44 & 42.18 & 38.87 & 34.74 \\
\hline Organic matter & 92.89 & 91.59 & 91.72 & 93.79 & 93.42 & 93.01 \\
\hline CP & 13.27 & 13.22 & 13.38 & 13.19 & 12.22 & 12.90 \\
\hline Crude fiber & 21.17 & 21.08 & 19.57 & 18.34 & 16.95 & 16.90 \\
\hline NDF & 22.59 & 23.71 & 23.00 & 22.59 & 24.56 & 23.23 \\
\hline ADF & 13.96 & 14.88 & 14.45 & 13.96 & 15.48 & 14.66 \\
\hline Crude fat & 4.85 & 4.79 & 4.27 & 4.30 & 3.18 & 3.61 \\
\hline Nitrogen Free Extract & 54.03 & 52.19 & 53.98 & 58.16 & 59.38 & 59.75 \\
\hline TDN & 67.04 & 66.76 & 67.71 & 68.52 & 69.21 & 68.93 \\
\hline Tannin & 0.05 & 0.08 & 0.14 & 0.05 & 0.06 & 0.16 \\
\hline
\end{tabular}

$\mathrm{TDN}=$ Total digestible nutrient, $\mathrm{RDP}=$ Rumen degradable protein, $\mathrm{RUP}=$ Rumen undegradable protein, NDF=Neutral detergent fiber, $\mathrm{ADF}=$ Acid detergent fiber, $\mathrm{CP}=$ Crude protein, $\mathrm{DM}=$ Dry matter 
Table-2: Chemical composition diet for protein 14\% DM.

\begin{tabular}{|c|c|c|c|c|c|c|}
\hline \multirow[t]{2}{*}{ Component } & \multicolumn{3}{|c|}{$65 \%$ TDN (DM) } & \multicolumn{3}{|c|}{ 70\% TDN (DM) } \\
\hline & RDP55 & RDP60 & RDP65 & RDP55 & RDP60 & RDP65 \\
\hline \multicolumn{7}{|l|}{ Ingredient composition (\%) } \\
\hline Elephant grass (Pennisetum purpureum) & 30 & 30 & 30 & 30 & 30 & 30 \\
\hline Leucaena leucocephala & 11 & 13 & 3 & 8 & 11 & 3 \\
\hline Indigofera zollingeriana & 8 & 5 & 16 & 2 & 7 & 11 \\
\hline Cassava (Manihot esculenta) & 8 & 7 & 10 & 9 & 23 & 21 \\
\hline Palm kernel cake (Elaeis guineensis) & 27 & 10 & 3 & 26 & 15 & 2 \\
\hline Maize (Zea mays) & 11 & 7 & 5 & 18 & 5 & 5 \\
\hline Rice bran (Oryza sativa) & 2 & 22 & 24 & 2 & 2 & 9 \\
\hline Tofu waste & 2 & 5 & 8 & 4 & 6 & 18 \\
\hline Mineral & 1 & 1 & 1 & 1 & 1 & 1 \\
\hline & 100 & 100 & 100 & 100 & 100 & 100 \\
\hline \multicolumn{7}{|l|}{ Chemical composition (\% DM) } \\
\hline DM & 89.25 & 89.29 & 89.20 & 88.83 & 89.61 & 89.69 \\
\hline RDP (\%CP) & 55.96 & 62 & 66.86 & 55.89 & 59.55 & 66.30 \\
\hline RUP (\%CP) & 43.04 & 37 & 32.14 & 43.11 & 39.45 & 32.70 \\
\hline Organic matter & 92.74 & 91.29 & 90.96 & 93.57 & 92.92 & 92.69 \\
\hline $\mathrm{CP}$ & 15.38 & 14.80 & 15.39 & 13.82 & 14.00 & 14.50 \\
\hline Crude fiber & 19.90 & 22.16 & 21.47 & 19.17 & 18.50 & 19.25 \\
\hline NDF & 25.63 & 25.59 & 24.85 & 23.25 & 25.40 & 23.69 \\
\hline ADF & 16.47 & 16.35 & 16.11 & 14.47 & 16.26 & 15.07 \\
\hline Crude fat & 4.48 & 5.02 & 4.85 & 4.53 & 3.75 & 4.35 \\
\hline Nitrogen-free extract & 53.42 & 49.68 & 49.45 & 56.27 & 56.78 & 53.85 \\
\hline TDN & 67.25 & 66.59 & 66.55 & 68.13 & 68.29 & 68.73 \\
\hline Tannin & 0.16 & 0.11 & 0.27 & 0.05 & 0.14 & 0.19 \\
\hline
\end{tabular}

TDN=Total digestible nutrient, RDP=Rumen degradable protein, RUP=Rumen undegradable protein, NDF=Neutral detergent fiber, $A D F=$ Acid detergent fiber, $N F E=$ Nitrogen-free extract, $C P=$ Crude protein, $D M=D r y$ matter

Table-3: Chemical composition diet for protein 16\% DM.

\begin{tabular}{|c|c|c|c|c|c|c|}
\hline \multirow[t]{2}{*}{ Component } & \multicolumn{3}{|c|}{$65 \%$ TDN (DM) } & \multicolumn{3}{|c|}{ 70\% TDN (DM) } \\
\hline & RDP55 & RDP60 & RDP65 & RDP55 & RDP60 & RDP65 \\
\hline \multicolumn{7}{|l|}{ Ingredient composition (\%) } \\
\hline Elephant grass (Pennisetum purpureum) & 30 & 30 & 30 & 30 & 30 & 30 \\
\hline Leucaena leucocephala & 14 & 5 & 2 & 17 & 14 & 3 \\
\hline Indigofera zollingeriana & 8 & 15 & 18 & 3 & 4 & 13 \\
\hline Cassava (Manihot esculenta) & 5 & 5 & 9 & 4 & 8 & 9 \\
\hline Palm kernel cake (Elaeis guineensis) & 28 & 21 & 3 & 22 & 9 & 2 \\
\hline Maize (Zea mays) & 5 & 2 & 4 & 17 & 15 & 5 \\
\hline Rice bran (Oryza sativa) & 6 & 16 & 20 & 2 & 2 & 9 \\
\hline Tofu waste & 3 & 5 & 13 & 4 & 17 & 28 \\
\hline Mineral & 1 & 1 & 1 & 1 & 1 & 1 \\
\hline & 100 & 100 & 100 & 100 & 100 & 100 \\
\hline \multicolumn{7}{|l|}{ Chemical composition (\% DM) } \\
\hline DM & 89.72 & 89.64 & 89.47 & 89.00 & 89.39 & 90.10 \\
\hline RDP (\%CP) & 56.06 & 61.04 & 67.45 & 55.86 & 60.41 & 67.67 \\
\hline RUP (\%CP) & 42.94 & 37.96 & 31.55 & 43.14 & 37.83 & 31.33 \\
\hline Organic matter & 92.07 & 91.29 & 91.18 & 92.90 & 93.16 & 92.48 \\
\hline $\mathrm{CP}$ & 16.18 & 16.23 & 16.21 & 15.54 & 15.80 & 16.79 \\
\hline Crude fiber & 21.69 & 22.58 & 21.47 & 19.60 & 19.33 & 21.19 \\
\hline NDF & 26.61 & 25.28 & 24.99 & 26.44 & 25.68 & 24.16 \\
\hline ADF & 17.23 & 16.41 & 16.28 & 16.95 & 16.40 & 15.49 \\
\hline Crude fat & 4.91 & 5.20 & 4.99 & 4.54 & 4.68 & 5.37 \\
\hline Nitrogen free extract & 49.71 & 47.65 & 48.30 & 53.49 & 48.28 & 47.66 \\
\hline TDN & 66.49 & 65.86 & 66.86 & 67.82 & 68.98 & 68.55 \\
\hline Tannin & 0.16 & 0.26 & 0.30 & 0.09 & 0.10 & 0.22 \\
\hline
\end{tabular}

TDN=Total digestible nutrient, RDP=Rumen degradable protein, RUP=Rumen undegradable protein, NDF=Neutral detergent fiber, $A D F=A c i d$ detergent fiber, $N F E=$ Nitrogen-free extract, $C P=$ Crude protein, $D M=$ Dry matter

a slaughterhouse from three Pesisir cattle with an average $\mathrm{BW} \pm 150 \mathrm{~kg}$ that were fed a diet of elephant grass and concentrate. Fresh rumen liquor was filtered using nylon $(100 \mu \mathrm{m}$ sieve size $)$ and filled into pre-warmed $\left(39^{\circ} \mathrm{C}\right)$ thermos flasks. Filtered rumen liquor was diluted with the buffer solution suggested by McDougall [12], at a ratio of 1:4 (rumen fluid:buffer solution). A $2.5 \mathrm{~g}$ sample was then incubated in each Erlenmeyer flask with $250 \mathrm{~mL}$ of mixed solution (rumen fluid and buffer) anaerobically by pumping 
$\mathrm{CO}_{2}$ gas into the flask, then sealing it with a rubber lid. Each flask was placed in a shaking incubator at a temperature of $39^{\circ} \mathrm{C}$, and a rotational speed of $100 \mathrm{rpm}$ for $48 \mathrm{~h}$. After incubation, microbial activity was stopped by immersing the flask in ice water, after which the $\mathrm{pH}$ was measured. Thereafter, the supernatant was separated by placing the content of each flask in centrifuge tubes at $3000 \mathrm{rpm}$ for $5 \mathrm{~min}$ at $4^{\circ} \mathrm{C}$. The resulting supernatant was stored in bottles in a freezer at $-18^{\circ} \mathrm{C}$ until $\mathrm{NH}_{3}$ and total volatile fatty acid (VFA) analysis could be completed. The $\mathrm{NH}_{3}$ levels were determined using the Conway and O'Malley method [13]. The total VFA levels were determined through steam distillation [14]. Microbial protein synthesis was determined using

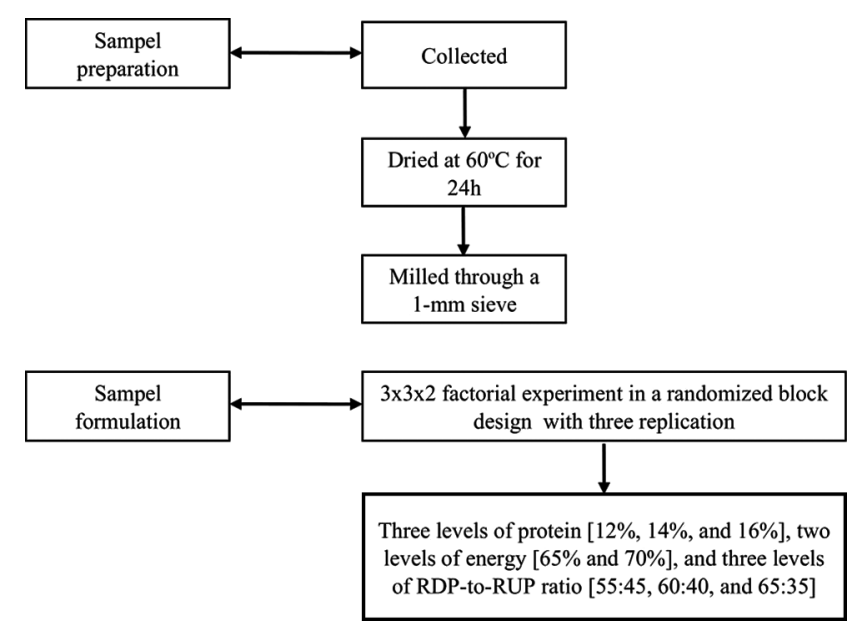

Figure-1: Flow diagram of sample preparation and formulation.
Lowry's method [15]. The residue was filtered using Whatman No. 41 filter paper, and then dried in an oven

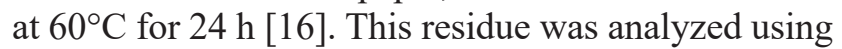
the Kjeldahl method to determine RUP digestibility. Subsequently, the feed digestibility was analyzed using the proximate analysis method [16]. A residue of $0.5 \mathrm{~g}$ was added to $40 \mathrm{ml} 2 \%$ pepsin- $\mathrm{HCl}$ and further incubated for $24 \mathrm{~h}$ to determine RUP digestibility [11].

\section{Statistical analysis}

This study was conducted using a factorial randomized block design. The obtained data were statistically analyzed using analysis of variances with Statistical Package for the Social Sciences (SPSS) software (IBM SPSS Statistics, USA) version 21.0 [17]. Data groups that showed a statistical significance $(p<0.05)$ were further analyzed using least significant difference tests.

\section{Results \\ Nutrient digestibility}

An increase in protein, energy, and RDP levels increased nutrient digestibility $(\mathrm{p}<0.05)$. They also increased DM digestibility from $58.94 \%$ to $75.61 \%$, organic matter digestibility from $60.13 \%$ to $76.97 \%$, and CP digestibility from $42.71 \%$ to $64.95 \%$. Rations with $16 \%$ protein lowered nutrient digestibility $(\mathrm{p}<0.05)$, and tended to decrease DM, organic matter, and CP digestibility. The digestibility of RUP in this experiment remained rather constant from $48.61 \%$ to $64.41 \%$. In vitro $\mathrm{DM}$, organic matter, $\mathrm{CP}$, and RUP digestibility are presented in Table- 4 .

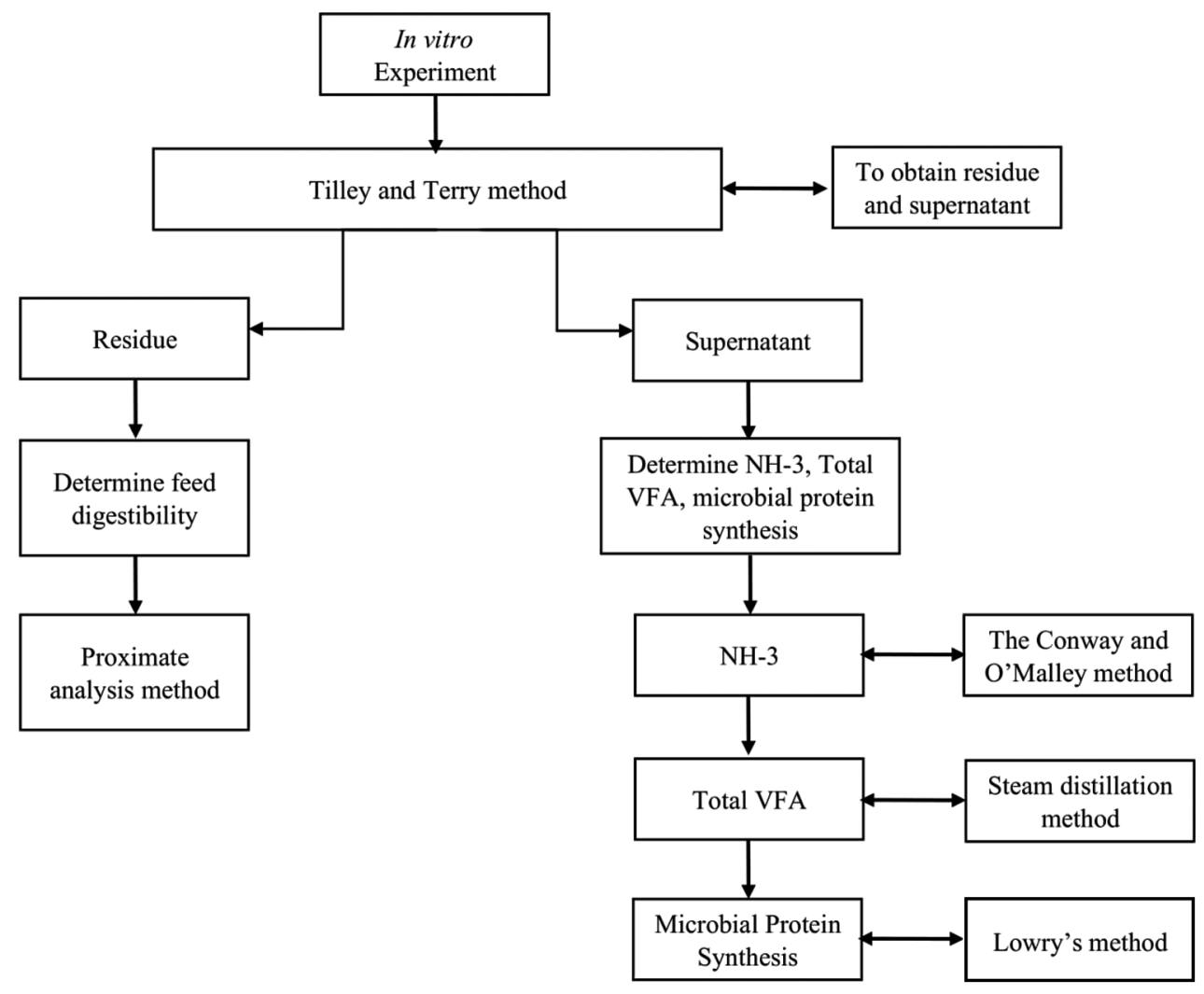

Figure-2: Flow diagram of the experimental methodology. 
Table-4: Nutrient digestibility of experimental diets.

\begin{tabular}{|c|c|c|c|c|c|c|}
\hline \multicolumn{3}{|c|}{ Factorial experiment } & \multicolumn{4}{|c|}{ Variables } \\
\hline Protein level (\% DM) & Energy level (\% DM) & RDP level (\% CP) & DMD (\%) & OMD (\%) & CPD (\%) & RUPD (\%) \\
\hline \multirow[t]{6}{*}{12} & 65 & 55 & $58.9^{9}$ & $60.13^{k}$ & $42.71^{k}$ & $60.69^{c, d, e}$ \\
\hline & & 60 & $59.01^{g}$ & $67.12^{\mathrm{h}}$ & $50.01^{i}$ & $55.27^{\mathrm{h}}$ \\
\hline & & 65 & $66.18^{e}$ & $62.58^{j}$ & $46.35^{j}$ & $56.01^{g, h}$ \\
\hline & 70 & 55 & $69.17^{d}$ & $69.45^{f}$ & $55.00^{\mathrm{h}}$ & $59.99^{c, d, e, f}$ \\
\hline & & 60 & $74.607^{a, b}$ & $74.49^{c, d}$ & $56.06^{\mathrm{f}, \mathrm{g}, \mathrm{h}}$ & $51.77^{i}$ \\
\hline & & 65 & $74.24^{\mathrm{b}}$ & $74.97^{c, d}$ & $57.35^{\mathrm{d}, \mathrm{e}, \mathrm{f}, \mathrm{g}}$ & $48.61^{\mathrm{j}}$ \\
\hline \multirow[t]{6}{*}{14} & 65 & 55 & $73.97^{b}$ & $74.39^{d}$ & $67.73^{a}$ & $55.64^{\mathrm{h}}$ \\
\hline & & 60 & $74.62^{a, b}$ & $75.04^{c, d}$ & $64.61^{b}$ & $60.21^{c, d, e, f}$ \\
\hline & & 65 & $74.41^{\mathrm{a}, \mathrm{b}}$ & $75.58^{b, c}$ & $60.8^{c}$ & $63.18^{a, b}$ \\
\hline & 70 & 55 & $75.01^{a, b}$ & $75.46^{b, c, d}$ & $64.95^{b}$ & $62.34^{a, b, c}$ \\
\hline & & 60 & $75.29^{a, b}$ & $76.5^{\mathrm{a}, \mathrm{b}}$ & $61.85^{c}$ & $58.07^{\mathrm{f}, \mathrm{g}}$ \\
\hline & & 65 & $75.61^{a}$ & $76.97^{a}$ & $64.54^{\mathrm{b}}$ & $53.81^{h, i}$ \\
\hline \multirow[t]{6}{*}{16} & 65 & 55 & $67.46^{e}$ & $67.96^{g, h}$ & $56.23^{e, f, g, h}$ & $58.49^{e, f}$ \\
\hline & & 60 & $66.75^{e}$ & $68.36^{f, g}$ & $58.49^{d}$ & $59.89^{\mathrm{d}, \mathrm{e}, \mathrm{f}}$ \\
\hline & & 65 & $70.56^{c}$ & $72.19^{e}$ & $58.01^{\mathrm{d}, \mathrm{e}}$ & $64.41^{\mathrm{a}}$ \\
\hline & 70 & 55 & $69.03^{d}$ & $69.42^{f}$ & $57.81^{\mathrm{d}, \mathrm{e}, \mathrm{f}}$ & $58.53^{e, f}$ \\
\hline & & 60 & $71.19^{c}$ & $72.36^{e}$ & $57.44^{d, e, f, g}$ & $60.16^{c, d, e, f}$ \\
\hline & & 65 & $63.05^{f}$ & $64.75^{i}$ & $55.60^{g, h}$ & $61.59^{b, c, d}$ \\
\hline SEM & & & 0.73 & 0.68 & 0.87 & 0.57 \\
\hline $\mathrm{P}$ & & & 0.05 & 0.05 & 0.05 & 0.05 \\
\hline
\end{tabular}

$a, b, c, d, e, f, g, h, i, j, k$ Superscript means significantly different in a column $(p<0.05)$. DMD =Dry matter digestibility, OMD=Organic matter digestibility, $\mathrm{CPD}=$ Crude protein digestibility, RUP=Rumen undegradable protein digestibility, $\mathrm{SEM}=\mathrm{Standard}$ error of mean

\section{Rumen fermentation characteristics}

Increased protein, energy, and RDP levels did not affect $\mathrm{pH}$, although there was a slight $\mathrm{pH}$ variation in the experimental diets $(\mathrm{p}>0.05) . \mathrm{NH}_{3}$ and total VFA tended to increase with increased protein, energy, and RDP levels $(\mathrm{p}<0.05) . \mathrm{NH}_{3}$ concentrations increased from 7.93 to $20.68 \mathrm{mM}$. Total VFA values increased from 93.33 to $151.67 \mathrm{mM}(\mathrm{p}<0.05)$. In contrast, $16 \%$ protein-rations tended to decrease $\mathrm{NH}_{3}$ concentrations from 11.05 to $9.07 \mathrm{mM}$ and decrease total VFA from 116.67 to $101.67 \mathrm{mM}$ (Table-5).

\section{Microbial protein synthesis}

Increased protein, energy, and RDP levels significantly increased microbial protein synthesis $(\mathrm{p}<0.05)$ from 93.65 to $139.25 \mathrm{mg} / 100 \mathrm{~mL}$. The $16 \%$ protein-rations tended to decrease microbial protein synthesis from 103.03 to $100.83 \mathrm{mg} / 100 \mathrm{~mL}$ (Table-5).

\section{Discussion}

\section{Nutrient digestibility}

The nutrient digestibility in this experiment increased with higher protein, energy, and RDP levels, indicating the beneficial effects of protein-energy synchronization and RDP levels on microbial protein synthesis. Nutrient digestibility correlated with the rumen microbial activity. An increase in the RDP level increased the availability of nitrogen for microbial protein synthesis, thus increasing microbe activity and their ability to digest feed. These results are in line with other studies that reported increased nutrient digestibility due to increased microbial activity as a result of increased RDP $[18,19]$. Conversely, an increase in RUP decreases $\mathrm{NH}_{3}$ levels and is a limiting factor in rumen microbial feed digestion activity.
The previous studies have also reported that feed with high RUP levels decrease NH3 and reduces digestibility $[7,20]$.

Increased nutrient digestibility indicates that the rumen is in better condition, leading to better fermentation. Better rumen fermentation and microbial activities lead to increased enzyme production, improved DM degradation, and decreased nutrient loss from the rumen. High digestibility improves ruminant productivity, because the nutrients can optimally utilize [5]. This improvement may also be due to the resulting nutrient abundance above what was required for improving digestibility. These results are in line with the previous studies [21,22], which stated that the availability of synchronized nutrient supply offered sufficient metabolic substrates for bacteria, which promoted their growth and increased nutrient digestibility. The ration with $16 \%$ protein levels tended to lower nutrient digestibility. We assumed that this ration could not reach an optimum protein-energy synchronization, which caused decreased microbial protein synthesis and nutrient digestibility.

Rumen undegraded protein digestibility (RUPD) is an important parameter in the updated protein evaluation systems for ruminant production and affects ruminant productivity. If RUP is indigestible, it supplies no metabolizable protein to the animal. In this experiment, RUPD varied among treatments but constantly ranged from $48 \%$ to $64 \%$. These results concur with a previous study [23], which stated that the RUP digestibility varied considerably from $25 \%$ to $60 \%$.

\section{Rumen fermentation characteristic}

Rumen $\mathrm{pH}$ did not significantly change with the increases in protein, energy, and RDP levels and 
Table-5: Rumen fermentation characteristic and microbial protein synthesis of experimental diets.

\begin{tabular}{|c|c|c|c|c|c|c|}
\hline \multicolumn{3}{|c|}{ Factorial experiment } & \multicolumn{4}{|c|}{ Variables } \\
\hline $\begin{array}{l}\text { Protein } \\
\text { level (\% DM) }\end{array}$ & $\begin{array}{c}\text { Energy } \\
\text { level (\% DM) }\end{array}$ & $\begin{array}{c}\text { RDP } \\
\text { level (\% CP) }\end{array}$ & $\mathbf{p H}$ & $\begin{array}{c}\text { NH3 } \\
(\mathrm{mg} / 100 \mathrm{~mL})\end{array}$ & $\begin{array}{c}\text { Total } \\
\text { VFA }(\mathrm{mM})\end{array}$ & $\begin{array}{c}\text { MPS } \\
(\mathrm{mg} / 100 \mathrm{~mL})\end{array}$ \\
\hline \multirow[t]{6}{*}{12} & 65 & 55 & 7.03 & $7.93^{h}$ & $93.33^{i}$ & $93.65^{g}$ \\
\hline & & 60 & 7.01 & $9.21^{f, g, h}$ & $96.67^{\mathrm{h}, \mathrm{i}}$ & $95.37^{g}$ \\
\hline & & 65 & 6.89 & $9.49^{f, g}$ & $103.33^{g, h, i}$ & $96.46^{f, g}$ \\
\hline & 70 & 55 & 6.98 & $9.92^{\mathrm{e}, \mathrm{f}, \mathrm{g}}$ & $113.33^{e, f, g}$ & $105.55^{c, d}$ \\
\hline & & 60 & 6.95 & $9.63^{f, g}$ & $110^{f, g}$ & $102.09^{\mathrm{d}, \mathrm{e}}$ \\
\hline & & 65 & 6.88 & $9.35^{f, g}$ & $106.67^{\mathrm{f}, g, \mathrm{~h}}$ & $100.87^{e, f}$ \\
\hline \multirow[t]{6}{*}{14} & 65 & 55 & 6.95 & $11.62^{d}$ & $123.33^{\mathrm{d}, \mathrm{e}}$ & $109.53^{c}$ \\
\hline & & 60 & 7.00 & $13.03^{c}$ & $136.67^{b, c}$ & $114.40^{b}$ \\
\hline & & 65 & 6.96 & $11.05^{\mathrm{d}, \mathrm{e}}$ & $116.67^{d, e, f}$ & $108.91^{c}$ \\
\hline & 70 & 55 & 6.95 & $17.28^{\mathrm{b}}$ & $146.67^{a, b}$ & $138.01^{\mathrm{a}}$ \\
\hline & & 60 & 6.98 & $19.83^{a}$ & $143.33^{a, b}$ & $137.09^{a}$ \\
\hline & & 65 & 6.92 & $20.68^{a}$ & $151.67^{a}$ & $139.25^{a}$ \\
\hline \multirow[t]{6}{*}{16} & 65 & 55 & 6.93 & $11.05^{\mathrm{d}, \mathrm{e}}$ & $116.67^{\mathrm{d}, \mathrm{e}, \mathrm{f}}$ & $103.03^{d, e}$ \\
\hline & & 60 & 7.22 & $10.48^{\mathrm{d}, \mathrm{e}, \mathrm{f}}$ & $126.67^{c, d}$ & $103.41^{\mathrm{d}, \mathrm{e}}$ \\
\hline & & 65 & 6.93 & $9.92^{e, f, g}$ & $106.67^{\mathrm{f}, g, \mathrm{~h}}$ & $102.05^{\mathrm{d}, \mathrm{e}}$ \\
\hline & 70 & 55 & 7.07 & $9.63^{f, g}$ & $103.33^{g, h, i}$ & $101.93^{\mathrm{d}, \mathrm{e}}$ \\
\hline & & 60 & 6.90 & $9.21^{\mathrm{f}, \mathrm{g}, \mathrm{h}}$ & $113.33^{e, f, g}$ & $102.62^{\mathrm{d}, \mathrm{e}}$ \\
\hline & & 65 & 6.96 & $9.07^{\mathrm{g}, \mathrm{h}}$ & $101.67^{g, h, i ~}$ & $100.83^{e, f}$ \\
\hline SEM & & & 0.04 & 0.51 & 2.46 & 1.95 \\
\hline p-value & & & 0.05 & 0.05 & 0.05 & 0.05 \\
\hline
\end{tabular}

$a, b, c, d, e, f, g, h, i, j$ Superscript means significantly different in a column $(p<0.05) . \mathrm{NH}_{3}=$ Ammonia, VFA=Volatile fatty acid, MPS=Microbial protein synthesis, $\mathrm{SEM}=$ Standard error of mean

was in the range of 6.88-7.22. This value is within the normal range of 5.5-7 [24]. In a previous study, an increased dietary protein did not affect $\mathrm{pH}$ [25]. A decrease or increase in rumen $\mathrm{pH}$ disrupts the growth of rumen microbes, especially protozoa, which are highly sensitive to low rumen $\mathrm{pH}$. As $\mathrm{pH}$ decreases, the energy normally used for the production of rumen microbial proteins is diverted to maintain a neutral $\mathrm{pH}$ in bacterial cells [26]. As RDP levels increased, rumen $\mathrm{pH}$ tended to decrease due to the tannins found in the legume used and the increased soluble carbohydrates in the diet. This is in line with the findings of a previous study [27], which reported that the addition of legumes tended to reduce rumen $\mathrm{pH}$, although not significantly.

As expected, the major effects of altering dietary $\mathrm{CP}$ and RDP levels on the ruminal fermentation patterns were reflected in changes in the ruminal $\mathrm{NH}_{3}-\mathrm{N}$ level [28]. A previous study showed that an increase in the dietary protein level increased the $\mathrm{NH}_{3}$ level [25], which indicates that protein can be utilized by microbes in the form of $\mathrm{NH}_{3}$. Furthermore, increased $\mathrm{NH}_{3}$ levels in the rumen indicate high soluble protein levels and high DM digestibility in the diet [26]. RDP plays an important role in regulating rumen $\mathrm{NH}_{3}$ levels. The RDP:RUP ratio varies depending on how proteins are degraded and how nitrogen is absorbed and utilized by microbes [29]. RDP is utilized by rumen microbes as a source of nitrogen in microbial protein synthesis.

$\mathrm{NH}_{3}$ is a product of rumen microbial activity from digesting protein feed sources [27,28]. Rumen microbes, especially proteolytic bacteria, utilize RDP feed sources by secreting protease enzymes to convert proteins into peptides. Proteolytic bacteria secrete the enzyme peptidase, which converts peptides into amino acids. Furthermore, deaminase enzymes secreted by proteolytic bacteria convert amino acids into $\mathrm{NH}_{3}$, which plays a role in microbial protein synthesis [30,31]. A previous study reported that microbial protein synthesis increases $\mathrm{NH}_{3}$ production by $6-21 \mathrm{mMol}$ [32]. In this study, $12 \%$ dietary protein levels increased $\mathrm{NH}_{3}$ from 7.93 to $9.92 \mathrm{mM}$, and the $14 \%$ dietary protein feed increased $\mathrm{NH}_{3}$ from 11.05 to $20.68 \mathrm{mM}$. Thus, it is likely that $\mathrm{NH}_{3}$ production could support microbial protein synthesis, indicating that the inclusion of legumes (I. zollingeriana and Leucaena leucocephala) provides organic matter for rumen microbial protein synthesis. This is in agreement with the findings of a previous study [33] that inclusion of I. zollingeriana at a high proportion provided sufficient organic material for rumen microbes, increased the fermentability profile, and increased the rate of rumen microbial protein synthesis.

In contrast, $16 \%$ dietary protein decreased $\mathrm{NH}_{3}$ levels from 11.05 to $9.07 \mathrm{mM}$. Thus, we assumed that microbial activity was not able to degrade the protein source into ammonia. As with microbial protein synthesis (Table-5), the microbial protein yield also decreased and affected the lower ammonia concentration in the rumen. Ammonia is an essential precursor for microbial protein synthesis in the rumen due to the inability of rumen microbes to directly transport amino acids into their cells [34]. Some other factors also affect the ammonia concentration in the rumen, such as protein fraction, rate of protein degradation, rate of passage, conversion efficiency of ammonia to 
microbial proteins, and clearance of ammonia from the rumen into the bloodstream [2].

Total VFA is a product of rumen microbial activity from digesting the energy source in the feed [25]. In this study, increased protein and RDP levels tended to increase the total VFA level. Specifically, the $12 \%$ dietary protein level increased the total VFA from 93.33 to $113.33 \mathrm{mM}$, and the $14 \%$ dietary protein increased the total VFA level from 123.33 to 151.67 $\mathrm{mM}$. Thus, increased total VFA increased nutrient digestibility. As shown in Tables-4 and 5, nutrient digestibility tended to increase with total VFA, because one of the products of nutrient degradation is VFA. This finding agrees with those of a previous study [31].

The $16 \%$ dietary protein level decreased total VFA from 126.67 to $101.67 \mathrm{mM}$ due to protein degradation and microbial protein synthesis. Decreased protein degradation and microbial protein synthesis decrease the production of total VFA, which is in line with Makmur et al. [35], who found that reduced degradation of feed proteins decreased VFAs and isoVFAs production. It has also been reported that variation in RDP levels alters total VFA levels [9]. The degradation of feed sources by microbes produces ATPs, which would be used by the host, and VFA, which would be utilized by rumen microbes as a carbon source to form microbial proteins $[8,36]$.

\section{Microbial protein synthesis}

Microbial protein synthesis occurs due to the synchronization of protein feed sources and energy sources [21], which must be easily degradable. An increase in RDP can maximize microbial protein synthesis, but an increase in the dietary RUP level reduces microbial protein synthesis, which results in decreased digestibility $[19,20]$. In this study, increased proteins and RDP levels increased microbial protein synthesis, because of the availability of nitrogen from $\mathrm{NH}_{3}$ and $\mathrm{C}$ from total VFA. In the $12 \%$ dietary protein feed, microbial protein synthesis increased from 93.65 to $105.55 \mathrm{mg} / 100 \mathrm{~mL}$, and the $14 \%$ dietary protein increased microbial protein synthesis from 108.91 to $139.25 \mathrm{mg} / 100 \mathrm{~mL}$. The $16 \%$ dietary protein decreased microbial protein synthesis from 103.41 to $100.83 \mathrm{mg} / 100 \mathrm{~mL}$. This indicates that protein-energy synchronization was not achieved. These findings agree with Lascano et al. [37] that efficient nutrient utilization and microbial protein synthesis can be achieved when ruminal reaction and protein and energy synchronization is optimal. Proteins are the most crucial source of nutrients for beef cattle, since they stimulate microbial protein synthesis and rumen fermentation, and improve productivity [38]. Increased microbial protein synthesis increases $\mathrm{NH}_{3}$ utilization and the effectiveness of fiber digestion, thus ensuring that the diet can be optimally used [26].

Approximately $50-80 \%$ of the amino acids absorbed are contributed from RDP to microbial protein synthesis $[21,36]$. It has also been reported that RDP can contribute as much as $100 \%$ to microbial protein synthesis in a forage-based or low-nutrient diet [38]. Proteins in poor-quality feed, in terms of amino acid profile and non-protein nitrogen, can be converted to high-quality proteins by rumen microbes. A major aspect of ruminant nutrients is the maximization of microbial growth and binding of RDP to microbial cells [39].

\section{Conclusion}

The present study confirms that an increase in dietary protein (from $12 \%$ to $14 \% \mathrm{DM}$ ), energy (from $65 \%$ to $70 \% \mathrm{DM}$ ), and RDP (from $55 \%$ to $65 \% \mathrm{CP}$ ) increased nutrient digestibility, $\mathrm{NH}_{3}$ concentration, total VFA levels, and microbial protein synthesis. The diet containing 14\% DM dietary protein and $70 \% \mathrm{DM}$ energy contained RDP 55\%, 60\%, and 65\% CP and is ideal to increase nutrient digestibility, $\mathrm{NH}_{3}$ concentration, total VFA levels, and microbial protein synthesis. These increases can reflect the benefit of RDP:RUP ration-based feeds to optimize the productivity of ruminants. Future research requires in vivo methods to determine the ideal RDP:RUP ratio in ruminant feeds.

\section{Authors' Contributions}

EMP, MZ, LW, and HH formulated the experimental design and experimental work at the laboratory. EMP drafted the manuscript and did data analysis under the guidance of MZ, LW, and $\mathrm{HH}$. All authors read and approved the final manuscript.

\section{Acknowledgments}

This study was supported by PMDSU(Master Education Program, Leading to a Doctoral Program for Superior Bachelor) Grant by the Ministry of Technology Research and Higher Education of Indonesia 2019 with grant number T/10/UN.16.17/ PT.01.03/PP/2019. This research would not have been possible without the technical assistance of the staff in the Laboratory of Ruminant Nutrition, Faculty of Animal Science, Andalas University, Indonesia.

\section{Competing Interests}

The authors declare that they have no competing interests.

\section{Publisher's Note}

Veterinary World remains neutral with regard to jurisdictional claims in published institutional affiliation.

\section{References}

1. Tedeschi, L.O., Fox, D.G., Fonseca, M.A., Francis, L. and Cavalcanti, L. (2015) Models of protein and amino acid requirements for cattle. R. Bras. Zootec., 44(3): 109-132.

2. Bach, A., Calsamiglia, S. and Stern, M.D. (2005) Nitrogen metabolism in the rumen. J. Dairy. Sci., 88 (E. Suppl): E9-E21.

3. Kaufman, J.D. (2016) Effect of Varying Rumen Degradable 
and Undegradable Protein on Milk Production and Nitrogen Efficiency in Lactating Dairy Cows under Summer Conditions, (Master of Science Degree). The University of Tennessee, Knoxville.

4. Owens, F.N., Qi, S. and Sapienza, D.A. (2014) Invited review: Applied protein nutrition of ruminants current status and future directions. Prof. Anim. Sci., 30(2): 150-179.

5. Sharif, M., Qamar, H. and Wahid, A.A. (2019) Effect of rumen degradable protein concentrations on nutrient digestibility, growth performance and blood metabolites in Beetal kids. Concepts Dairy Vet. Sci., 2(5): 249-253.

6. Hall, M.B. (2013) Dietary starch source and protein degradability in diets containing sucrose: Effects on ruminal measures and proposed mechanism for degradable protein effects. J. Dairy. Sci., 96(11): 7093-7109.

7. Bahrami-yekdangi, M., Ghorbani, G.R., Khorvash, M., Khan, M.A. and Ghaffari, M.H. (2016) Reducing crude protein and rumen degradable protein with a constant concentration of rumen undegradable protein in the diet of dairy cows: Production performance, nutrient digestibility, nitrogen efficiency, and blood metabolites. J. Anim. Sci., 94(2): 718-725.

8. Brooks, M.A., Harvey, R.M., Johnson, N.F. and Kerley, M.S. (2012) Rumen degradable protein supply effects microbial efficiency in continuous culture and growth in steers. $J$. Anim. Sci., 90(13): 4985-4994.

9. Paula, E.M., Monteiro, H.F., Silva, L.G., Benedeti, P.D.B., Daniel, J.L.P., Shenkoru, T. and Faciola, A.P. (2016) Effects of replacing soybean meal with canola meal differing in rumen-undegradable protein content on ruminal fermentation and gas production kinetics using 2 in vitro systems. $J$. Dairy Sci., 100(7): 5281-5292.

10. Putri, E.M., Zain, M., Warly, L. and Hermon, H. (2019) In vitro evaluation of ruminant feed from West Sumatera based on chemical composition and content of rumen degradable and rumen undegradable proteins. Vet. World, 12(9): 1478-1483.

11. Tilley, J.M. and Terry, R.A. (1963) A two-stage technique for in vitro digestion of forage crops. J. Br. Grassland Soc., 18(2): 104-111.

12. McDougall, E.I. (1947) Studies on ruminant saliva. 1. The composition and output of sheep's saliva. Biochem. J., 43(1): 99-109.

13. Conway, E.J. and O'Malley, E. (1942) Microdiffusion methods. Ammonia and urea using buffered absorbents (revised methods for ranges greater than $10 \mu \mathrm{g}$. N). Biochem. J., 36(7-9): 655-661.

14. Prosedure, G.L. (1996) Departement of Dairy Science. University of Wisconsin, Wisconsin.

15. Lowry, O.H., Rosebrough, N.J., Farr, A.L. and Randall, R.J. (1951) Protein measurement with the Folin reagent. J. Biol. Chem., 193(1): 265-275.

16. Association of Official Analytical. (2005) Official Methods of Analysis. $18^{\text {th }}$ ed. Association of Official Analytical, Chemists International, Maryland, USA.

17. SPSS. (2012). IBM SPSS Statistics for Windows, Version 21.0. IBM Corp, Armon, NY.

18. Chandrasekharaiah, M., Thulasi, A., Suresh, K.P. and Sampath, K.T. (2011) Rumen degradable nitrogen requirements for optimum microbial protein synthesis and nutrient utilization in sheep fed on finger millet straw (Eleucine coracana) based diet. Anim. Feed Sci. Technol., 163(2-4): 130-135.

19. Javaid, A., Shahzad, M.A., Nisa, M. and Sarwar, M. (2011) Ruminal dynamics of ad libitum feeding in buffalo bulls receiving different level of degradable protein. Livest. Sci., 135(1): 89-102.

20. Akhtar, M., Nisa, M. and Javais, J. (2017) Effect of varying levels of dietary rumen undegradable protein on dry matter intake, nutrient digestibility and growth performance of crossbred cattle heifers. Gomal Univ. J. Res., 33(2): 58-67.
21. Hermon, H., Suryahadi, S., Wiryawan, K.G. and Hardjosoewignjo, S. (2008) Synchronized ratio of n-protein and energy supply in the rumen as a basis for ruminant animal ration formulation. Media Peternakan, 31(3): 186-194.

22. Hao, X.Y., Diaoa, X.G., Yu, S.C., Ding, N., Mu, C.T., Zhao, J.X. and Zhang, J.X. (2018) Nutrient digestibility, rumen microbial protein synthesis, and growth performance in sheep consuming rations containing sea buckthorn pomace. J. Anim. Sci., 96(8): 3412-9.

23. Buckner, C.D., Klopfenstein, T.J., Rolfe, K.M., Griffin, W.A., Lamothe, M.J., Watson, A.K., MacDonald, J.C., Schacht, W.H. and Schroeder, P. (2013) Ruminally undegradable protein content and digestibility for forages using the mobile bag in situ technique. J. Anim. Sci., 91(6): 2812-2822.

24. Puniya, A.K., Singh, R. and Kamra, D.N. (2015) Rumen Microbiology: From Evolution to Revolution. Springer, New Delhi.

25. Yang, C., Bing-Wen, S., Qi-Yu, D., Hai, J., Shu-Qin, Z. and Yan, T. (2016) Rumen fermentation and bacterial communities in weaned Chahaer lambs on diets with different protein levels. J. Integr. Agric., 15(7): 1564-1574.

26. Uddin, J.M., Haque, K.Z., Jasimuddin, K.M. and Hasan, K.M.M. (2015) Dynamics of microbial protein synthesis in the rumen a review. Ann. Vet. Anim. Sci., 2(5): 2312-9123

27. Zain, M., Putri, E.M., Rusmana, W.S.N., Erpomena. and Makmur, M. (2020) Effects of Supplementing Gliricidia sepium on ration based ammoniated rice straw in ruminant feed to decrease methane gas production and to improve nutrient digestibility (in-vitro). Int. J. Adv. Sci. Eng. Inf. Technol., 10(2): 724-729.

28. Mutsvangwa, T., Davies, K.L., McKinnon, J.J. and Christensen, D.A. (2016) Effects of dietary crude protein and rumen-degradable protein concentrations on urea recycling, nitrogen balance, omasal nutrient flow, and milk production in dairy cows. J. Dairy. Sci., 99(8): 6298-6310.

29. Tacoma, R., Fields, J., Ebenstein, D.B., Lam, Y.W. and Greenwood, S.L. (2017) Ratio of dietary rumen degradable protein to rumen undegradable protein affects nitrogen partitioning but does not affect the bovine milk proteome produced by mid-lactation Holstein dairy cows. J. Dairy. Sci., 100(9): 7246-7261.

30. Das, L.K., Kundu, S.S., Kumar, D. and Datt, C. (2014) Metabolizable protein systems in ruminant nutrition: A review. Vet. World, 7(8): 622-629.

31. Ningrat, R.W.S., Zain, M., Erpomen, Putri, E.M. and Makmur, M. (2019) Effects of Leucaena leucocephala supplementation to total mixed ration based on ammoniated rice straw on fiber digestibility and rumen fermentation characteristics in vitro. Int. J. Adv. Sci. Eng. Inf. Tech., 9(3): 916-921.

32. McDonald, P., Edwards, R.A., Greenhalgh, J.F.D., Morgan, C.A., Sinclair, L.A. and Wilkinson, R.G. (2002) Animal Nutrition. $6^{\text {th }}$ ed. Prentice Hall, London.

33. Makmur, M., Zain, M., Agustin, F., Sriagtula, R. and Putri, E.M. (2020a) In vitro rumen biohydrogenation of unsaturated fatty acids in tropical grass-legume rations. Vet. World, 13(4): 661-668.

34. Jayanegara, A., Novandri, B., Yantina, N. and Ridla, M. (2017) Use of black soldier fly larvae (Hermetia illucens) to substitute soybean meal in ruminant diet: An in vitro rumen fermentation study. Vet. World, 10(12): 1439-1446.

35. Makmur, M., Zain, M., Marlida, Y., Khasrad, K. and Jayanegara, A. (2020b) In vitro ruminal biohydrogenation of $\mathrm{C} 18$ fatty acids in mixtures of Indigofera zollingeriana and Brachiaria decumbens. J. Indones. Trop. Anim. Agric., 45(2): 124-135.

36. Hackmann, T.J. and Firkins, J.L. (2015) Maximizing efficiency of rumen microbial protein production. Front. Microbiol, 6(465):1-16

37. Lascano, G.J., Koch, L.E. and Heinrichs, A.J. (2016) 
Precision-feeding dairy heifers a high rumen-degradable protein diet with different proportions of dietary fiber and forage-to-concentrate ratios. J. Dairy Sci., 99(9): 7175-7190.

38. Wanapat, M. (2009) Potential uses of local resources for ruminants. Trop. Anim. Health Prod., 41(7): 1035-1049.

39. Givens, D.I., Owen, E. and Adesogan, A.T. (2000) Current procedures, future requirements and the need for standardization. In: Forage Evaluation in Ruminant Nutrition. Cabi Publishing, Wallingford. p449-474.

$* * * * * * * *$ 